\title{
Using Anti-Nuclear Antibody and Rheumatoid Factor to Evaluation of Immune- Pathogenic Link of Rheumatoid Arthritis and Hepatitis C Virus in Iraqi Patients
}

\author{
Mohammed A. Saleh \\ Department of Biology, College of Science, Diyala University, Diyala-Iraq. \\ E-mail: Mohammed mostafa 78@yahoo.com.
}

\begin{abstract}
This study was aimed to assess immune- pathogenic association of HCV infection among RA patients. A cross sectional study was conducted on the following groups: patient group includes forty patients with RA. Their age range was between (20-70) years with (7) (17.5\%) males and (33) $(82.5 \%)$ females. Healthy Group: thirteen serum samples were collected from apparently healthy individuals they served as a control group.Their age range was between (23-59) years. Results of this study reveals that the majority of RA patients are females $(82,5 \%)$ with females to males ratio of 4.7: 1 . Moreover, the mean of age for RA and control groups are (46.83 \pm 12.06$)$ and $(45.23 \pm$ 12.58), respectively. The prevalence of RA among RA females was $(82.5 \%)$ and $(17.5 \%)$ for male and the frequency of rheumatoid Factor positivity among RA patients was (70\%) in comparison with $(0.0 \%)$ for apparently healthy control group with significant differences $(\mathrm{P} \leq 0.001)$. Also, ANA positivity was higher $(27,5 \%)$ than that for healthy control group $(0.0 \%)$ with significant differences $(\mathrm{P} \leq 0.005)$. Results showed that, the frequency of positivity anti-HCV Ab was $(5 \%)$ among RA patients in comparison with apparently healthy control group $(0 \%)$. Our results sustain the possible contribution of HCV infection in the pathogenesis of RA.
\end{abstract}

Keywords: Rheumatoid Arthritis, Hepatitis C Virus, Anti-Nuclear Antibody.

\section{Introduction}

Hepatitis $\mathrm{C}$ virus (HCV) infection has become a major public health problem, with 170 million people are infected worldwide. The disease progresses slowly and a chronic infection develops in $85 \%$ of the cases. Among patients with chronic hepatitis, 20 to $30 \%$ develop cirrhosis that, once established, carries a poor prognosis, with a high risk of developing hepatocarcinoma [1].

Autoimmune manifestations are common in patients chronically infected by HCV [2]. These manifestations can be dominant, while the hepatic disease can be quiescent or mild. There has been growing interest in the relationship between $\mathrm{HCV}$ and Sjogren's syndrome (SS), rheumatoid arthritis (RA) and systemic lupus erythematosus (SLE) [3].

Rheumatoid arthritis usually presents as an unresolving polyarthritis of small joints with or without large joint involvement. RA is an autoimmune disease of multifactorial etiology. Although genetic predisposition (including the presence of particular HLA-DR4 and/or DR1 alleles) is significant in the development, clinical course, severity, and expression of extraarticular manifestations, the cause of RA remains elusive [4].

Many viruses and bacteria have been implicated as causative agents. These include the Epstein-Barr virus, parvovirus B19, hepatitis $\mathrm{C}$ and Rubella and bacterial organism such as Mycoplasma, mycobacterium and Yersina [5]. It has been suggested that these organism infect host cell and alter the reactivity or responsiveness of the $\mathrm{T}$ - cells of the immune system sufficiently to trigger the disease [6].

The worldwide prevalence of arthritis presumed to be due to hepatitis $\mathrm{C}$ virus (HCV) infection has been reported between 2.4 million and 45.9 million people [7]. Finally, serum anti-HCV antibodies were detected in $5.2 \%$ and $7.6 \%$ of patients with RA[8,9], thus a causal link might exist between $\mathrm{HCV}$ and RA in some patients. The objective of this study was to determine if there is a possible relation between RA and $\mathrm{HCV}$ infection by evaluating the immune- pathogenic link of this infection among patients with RA. 


\section{Materials and Methods \\ Subjects}

A cross sectional study was conducted on the following groups in the period between January 2010 to August 2010.

\section{Patient Study Group}

This group included forty patients with RA. Those patients had RA as defined by the American Rheumatism Association (ACR). These patients attended the Rheumatology Department of Baghdad Teaching Hospital during the study period between January 2010 to August 2010. The diagnosis of those patients was performed under the supervision of rheumatic disease Consultant Rheumatologist. Their age range was between (20-70) years with (7) (17.5\%) males and (33) $(82.5 \%)$ females. Those patient who had history or clinical evidence of RA which includes: insidious pain, stiffness, erythema warmth and symmetric joint swelling. This work was done in Baghdad teaching hospital / medical city, immunological departments in teaching laboratories/ medical city and viral hepatitis reference laboratory.

\section{Healthy Control Group}

Thirteen apparently healthy volunteers included in this study as a control group. Their age range was between (23-59) years with (1) male and (12) females. Those healthy who have no history or clinical evidence of RA or any other chronic disease, and no obvious abnormalities.

\section{Sample Collection}

From each individual included in this study, 5-10 $\mathrm{ml}$ of blood was drawn by vein puncture using disposable syringes. The blood was placed in plastic disposable plane tubes, it was left to stand at room temperature (20$25^{\circ} \mathrm{C}$ ) to allow it to clot, then the sera was separated by centrifugation for 5 minutes, and divided into aliquots $(250 \mu \mathrm{l})$ and stored at $-20^{\circ} \mathrm{C}$ till examination. Each aliquot of the serum was used once to avoid thawing and freezing. All sera and reagents were allowed to stand at room temperature before use in the test.

\section{Methods}

Immunological markers

\section{A.Enzyme linked immunoassay for Rheumatoid Factor detection}

Diluted serum sample (1: 20) was incubated with the specific antigen which coated micro titer plate's wells. Patient's antibodies, if present in the specimen, combined with the antigen. Un-bound fraction was washed off in the following step. Afterwards anti-human immunoglobulins conjugated to horse radish Peroxidase (HRPconjugate) are incubated and reacted with the Antigen-Antibody complex of the sample in the micro wells. Un-bound conjugate was washed off by washing solution. Addition of Tetra-Methyl Benzydine (TMB-substrate) generates an enzymatic colorimetric (blue) reaction, which was stopped by diluted acid solution to yield yellow discoloration. The rate of color formation from the chromogen was proportional to the initial concentration of the respective Abs in the patient's sample. Microtiter plate reader at $450 \mathrm{~nm}$ was the reading filter and optional $620 \mathrm{~nm}$ [10]. The detailed procedure was carried out as has been suggested in the leaflet supplied with the test kit (Omega, UK). This method was done in immunological departments in teaching laboratories/ medical city.

\section{B.Indirect Immunoflurescent Antibody Test for Antinuclear Antibody (ANA) Detection}

In indirect immunoflurescent technique, the patient serum was incubated with a suitable substrate to allow specific binding and formation of a stable antigen-antibody complex in the presence of specific antibody. After washing, the substrate is incubated with fluorescein conjugated antihuman globulin reagent to give three-part complex which emits in the fluorescent microscope [11]. Substrate slide: HEP-2 cell line for ANA detection was used, $25 \mu \mathrm{L}$ of dilution of patient serum (1/40) was layered over the substrate and allowed to incubate at room temperature in a moist chamber for $20 \mathrm{~min}$, the slide was then washed with a stream of phosphate buffer saline (P.B.S) pH 7.4 and left in a staining dish filled with PBS for 1 minute with a magnetic stirrer. After that, the slide was removed, excess PBS was removed by blotting strips and placed in moisture chamber 
to add $25 \mu \mathrm{L}$ of fluoresce in conjugated antisera to human Immunoglobulins to each well and washed for mounted using mount media (buffered polyvinyl alcohol ) to be examined under fluorescent microscope in a dark room[11].

\section{Virological Marker}

\section{A.ELISA for Detection of Antibodies to HCV (Screening Test) :}

This is an immune- enzymatic method in which the wells of a micro titer plate were coated with recombinant antigens (Ags) representing epitopes of $\mathrm{HCV}$. Serum or plasma samples were added to these wells. If the Abs specific for $\mathrm{HCV}$ are present in the sample, they form stable complexes with the HCV Ag in the well. After washing to remove the unbound material a rabbit anti-human IgG labeled with Horse Radish Peroxidase HRP (as conjugate) was added and, if the $\mathrm{Ag} / \mathrm{Ab}$ complex is present, the conjugate will bind to the complex. After a second wash, an enzyme substrate solution containing a chromogen was added. This solution develops a blue color if the sample is positive. The blue color changes to yellow after blocking the reaction with sulphuric acid. The intensity of color is proportional to the anti-HCV Abs concentration in the sample. Wells containing negative samples remain colorless [12].

\section{B. Immunoblot Anti-HCV (Confirmatory Test) :}

This method was done in viral hepatitis reference laboratory /Baghdad.

The present immunoblot makes use of gene technology produced virus antigen. Four recombinant $\mathrm{HCV}$ antigens are used into the test strips:

- Core, Capsid antigen.

- NS-3, encoding the viral protease and helicase.

- NS-4, N-terminal part of NS.

The detailed procedure was carried out as has been suggested in the leaflet supplied with the test kit (Bayer health care, U.S.A) [13].

\section{Results and Discussion}

Forty patients (33 women, 7 men) who age range (20-70 years) were studied. The demographical picture of studied group (RA patients and healthy control group) are listed in the Table (1). This table reveals that the majority of RA patients are females $(82,5 \%)$ with females to males ratio of $4.7: 1$. Moreover, the mean of age for RA and control groups are $(46.83 \pm 12.06)$ and $(45.23 \pm$ $12.58)$, respectively.

Table (1)

Distribution of the study groups according to gender and age groups.

\begin{tabular}{|c|c|c|c|c|}
\hline \multirow[b]{2}{*}{ Variables } & \multicolumn{2}{|c|}{$\begin{array}{l}\text { Rheumatoi } \\
\text { d arthritis }\end{array}$} & \multicolumn{2}{|c|}{$\begin{array}{l}\text { Healthy } \\
\text { control }\end{array}$} \\
\hline & No & $\%$ & No & $\%$ \\
\hline Sex Male & 7 & 17.5 & 1 & 7.7 \\
\hline Female & 33 & 82.5 & 12 & 92.3 \\
\hline $\begin{array}{c}\text { Age (years) } \\
20-29\end{array}$ & 4 & 10.0 & 2 & 15.4 \\
\hline $30-39$ & 5 & 12.5 & 2 & 15.4 \\
\hline $40-49$ & 13 & 32.5 & 2 & 15.4 \\
\hline $50-59$ & 12 & 30.0 & 5 & 38.5 \\
\hline $60-69$ & 4 & 10.0 & 2 & 15.4 \\
\hline$\Rightarrow>70$ & 2 & 5.0 & - & - \\
\hline $\begin{array}{l}\text { Mean } \pm \text { SD } \\
\text { (Range) }\end{array}$ & \multicolumn{2}{|c|}{\begin{tabular}{|c}
$46.83 \pm 12.0$ \\
$6(20-70)$
\end{tabular}} & \multicolumn{2}{|c|}{$\begin{array}{c}45.23 \pm 12.58 \\
(26-61)\end{array}$} \\
\hline
\end{tabular}

Rheumatoid arthritis is one of the most common autoimmune diseases, affecting $0.5 \%$ of the population [14]. In this current study, the mean age for RA patients was at the fourth decade $(46.83 \pm 12.06$ years $)$ which is in agreement with previous studies [15,20].

Moreover, the prevalence of RA among RA females was $(82.5 \%)$ and $(17.5 \%)$ for male. This frequency is higher to some extent, with that of local previous studies in Iraq which are mentioned by [16,17] who noticed the lower percentage which reached to (70.7) and (79.7) \% respectively. These results may be due to the environmental conditions beside the psychological situation of Iraqi people which results in high stress that enhance RA development. Also higher prevalence was noticed in North American families (76.8\%) [18]. This result denoted a high frequency among females rather than males which may be due to the hormonal differences between them and in turn, their effects on the immune responses [19]. Furthermore, the frequency of rheumatoid Factor (RF) positivity rate among RA patients is $(70 \%)$ in comparison with $(0.0 \%)$ for apparently healthy control group 
with significant differences $(\mathrm{P} \leq 0.001)$. Additionally, ANA positivity rate was higher $(27,5 \%)$ than that for healthy control group $(0.0 \%)$ with significant differences $(\mathrm{P} \leq 0.005)$ (Table (2)).

Data have been analyzed statistically using SPSS program version 10. Analysis of quantitative data was done using t-test and ANOVA (analysis of variance). Acceptable level of significance was considered to be below 0.05 [26].

The Positivity rate of RF was observed in (70\%) of Iraqi patients, it seemed which done by Iraqi researchers which were $(53.3 \%$, $57.7 \%$ ) respectively $[16,20]$, while other study found high positivity of RF (85\%) [21]. These differences may be due to most of the samples related to well-established RA patients who were undergone treatment which lower RF titer below the significant level. The Positivity of ANA was shown in (27.5\%) of RA patients in comparison with $(0.00 \%)$ of healthy control groups. These results agree with the fact that variable types of auto antibodies occur during RA course such as ANA, though they appear in low frequency. The current results are comparable with the results that reported by Al-Naqdy et al. [22] for RA patients, though they were varied from place to another with the variation in the circumstances and the methods that applied such ELISA or Immunoflurescent assay.

Besides, the frequency of positivity Anti$\mathrm{HCV} \mathrm{Ab}(5 \%)$ among RA patients in comparison with apparently healthy control group.This is similar to the $5.5 \%$ in the study of Hsu et al [23] as well as Similar finding for Anti-HCV Ab among RA patients determination have been reported by some studies [2,6].The results of this study was higher than that reported in France $(1 \%)$ in which ELISA II was used [24]; but lower than those obtained in Italy (6\%) [5], and Spain (11\%) [25]. These differences may be due to the use of different methods for $\mathrm{HCV}$ detection, distinct populations, and to the geographical variability in the prevalence of $\mathrm{HCV}$ infection observed in different countries [24].

Autoimmunity and viral infections such as hepatitis $C$ virus are closely related fields, and viruses have been proposed as possible etiological or triggering agents of autoimmune disorders (ADs). Various viruses have been implicated in the cause and pathogenesis of rheumatoid arthritis (RA). Hepatitis $\mathrm{C}$ virus (HCV) infection, which has been recognized as a cause of some autoimmune diseases, and which has been described as sometimes presenting with rheumatic manifestations.

\section{Conclusion}

Our results support the possible participation of $\mathrm{HCV}$ infection in the immunopathogenesis of RA. However, further studies are recommended for a better understanding of the influence of $\mathrm{HCV}$ infection on the clinical course of RA and vice-versa.

Table (2)

The frequency of anti-HCV antibodies and anti-nuclear antibodies markers among studied group.

\begin{tabular}{|c|c|c|c|c|c|}
\hline \multirow[t]{2}{*}{ Markers } & \multicolumn{2}{|c|}{$\begin{array}{l}\text { Rheumat } \\
\text { oid } \\
\text { arthritis }\end{array}$} & \multicolumn{2}{|c|}{$\begin{array}{c}\text { Healthy } \\
\text { control }\end{array}$} & \multirow[t]{2}{*}{$\begin{array}{c}P \\
\text { value }\end{array}$} \\
\hline & No & $\%$ & No & $\%$ & \\
\hline $\begin{array}{l}\text { Anti-HCV } \\
\text { Ab Positive }\end{array}$ & 2 & 5.0 & - & - & - \\
\hline Negative & 38 & 95.0 & 13 & 100.0 & \\
\hline $\begin{array}{c}\text { ANA } \\
\text { positive }\end{array}$ & 11 & 27.5 & - & - & 0.005 \\
\hline Negative & 29 & 72.5 & 13 & 100.0 & \\
\hline $\begin{array}{c}R F \\
\text { Positive }\end{array}$ & 28 & 70 & 0 & 0.0 & 0.001 \\
\hline Negative & 12 & 30.0 & 13 & 100.0 & \\
\hline
\end{tabular}

\section{References}

[1] Lauer, G.M. and Walker, B.D. "Hepatitis C virus infection"; J. N. Engl. Med. 345, 41-52, 2001.

[2] Clifford, B.D.; Donahue, D.; Smith, L.; Cable, E.; Luttig,B. and Manns, M. "High prevalence of serological markers of autoimmunity in patients with chronic hepatitis C"; Hepatol. 21, 613-619, 1995.

[3] Ramos-Casals, M.; Garcia-Carrasco, M.; Cervera, R.; Rosas, J.; Trejo, O. and delaRed,G. "Hepatitis C virus infection mimicking primary Sjogren syndrome. A clinical and immunologic description of 35 cases"; Medicine. 80, 1-8, 2001. 
[4] Buch, M. and Emery, P. "The Etiology and Pathogenesis of rheumatoid arthritis". J. Hospital Pharmacist. 9, 5-10, 2002.

[5] Stransky, G.; Vernon, J. and Aicher, W. "Virus-like particles in synovial fluid from patients with rheumatoid arthritis"; J. Rheumatol. 32, 1044, 1993.

[6] Olivieri, I.; Palazzi, C. and Padula, A. "Hepatitis C virus and arthritis". Rheum. Dis. Clin. North Amer. 29,111-122, 2003.

[7] Rosner, I.; Rozenbaum, M.; Toubi, E.; Kessel, A.; Naschitz, J.E.; Zuckerman, E. "The case for hepatitis C arthritis"; Semin. Arthr. Rheum. 33,375-387, 2004.

[8] Taglione, E.; Vatteroni, M.L.;Martini,P.; Galluzzo, E. and Lombardini, F. "Hepatitis $\mathrm{C}$ virus infection: prevalence in psoriasis and psoriatic arthritis" ; J. Rheumatol. 26,370-372,1999.

[9] Rivera,J.; Garcia-Monforte, A.; Pineda, A. and Millan, J. "Arthritis in patients with chronic hepatitis C virus infection" ; J. Rheumatol. 26,420-424,1999.

[10] Bennett,R.H. and Burch TA. "New York symposium on population studies in the rheumatic disease: new diagnostic criteria"; Ann. Intern. Med. 17, 453-458, 2004

[11] Van-Boekel,M."Autoantibody system in Rheumatoid arthritis: specificity, sensitivitiy and diagnostic"; Arthri. Res. 4,87-93, 2002.

[12] Countreras,M.and Barbara,J." Screening for hepatitis C antibodies"; The Lancet. 2,505, 1989.

[13] Gretch, D.R." Diagnostic test for hepatitis C". Hepatol., 26, 43-47,1997.

[14] Shankar, S. and Handa, R. (2009). Biological agents in Rheumatoid arthritis. Postgrade Med. 50, 293-299, 2009.

[15] El-saffar, J. "Role of Anti-Cyclic citrullinated peptide antibodies and interleukin -2,6 in diagnosis of rheumatoid arthritis in Iraqi patients", $\mathrm{PhD}$ thesis. College of Science, University of Baghdad, 2008.

[16] Abdul-Abbas, H. "Correlation between rheumatoid arthritis and some cytokines among Iraqi rheumatoid arthritis patients", Msc thesis,College of Health and Medical Technology, Foundation of Medical Education, 2007.
[17] Al-Haidary, B. "HLA typing for rheumatoid arthritis patients (familial profile)", $\mathrm{PhD}$ thesis, College of Medicine, University of Baghdad, 2003.

[18] Jawaheer, D.; Raymond, L.; Gregersen, P. and Criswell, L. "Influence of male sex on disease phenotype in familial rheumatoid arthritis"; Arth. and Rheum. 5, 3087-3094, 2006.

[19] Koopmans, W. "Prospects for Autoimmune disease"; JAMA. 285, 648649, 2001.

[20] Al-Rawi, Z.S.; Azzawi, A.J.; Al-Ajili, F.M. and Al-Wakil, R. "RA in Population Samples in Iraq"; Ann. Rheum. Dis. 37, 73-75, 1998.

[21] Anaya, J.; Correa, P.; Mantilla, R. and Arcos-Burgos, M. "Rheumatoid arthritis association in Colombian population is restricted to HLA-DRB1"; Gene Immun. 3, 56-58, 2002.

[22] Al-naqdy, A.; Al-Busaidy, J. and Hassan, B. "Evaluation of Anti-dsDNA antibodies in anti-nuclear antibody positive Omani patients"; Pak. J. Med. Sci. 23, 211-215, 2007.

[23] Hsu, F.C.;Starkebaum, G.; Boyko, E.J. and Dominitz,J.A." Prevalence of rheumatoid arthritis and hepatitis $\mathrm{C}$ in those age 60 and older in a US population based study"; J. Rheumatol. 30, 455-458, 2003.

[24] Maillefert, J. F.; Muller, G .; Falgarone, G. and Bour, J.B."Prevalence of hepatitis $C$ virus infection in patients with rheumatoid arthritis"; Ann. Rheum. Dis. 61,635-637, 2002.

[25] Lovy, M.R.; Starkebaum, G.and Uberoi, S."Hepatitis C Infection Presenting with Rheumatic Manifestations/ A Mimic of Rheumatoid Arthritis"; J. Rheumato. 23, 979-983, 1996.

[26] Sorlie, D.E. "Medical biostatistics and Epidemiology: Examination and board review". First ed. Appleton and Lange, Norwalk, Connecticut. PP : 47-88 ; 1995. 
الخلاصة

هدفت هذه الدراسة إلى أثبات العلاقة مابين التهاب

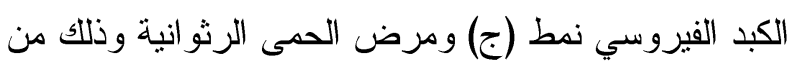

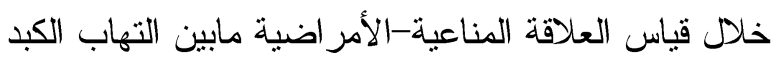

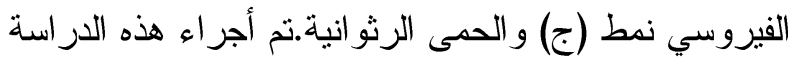

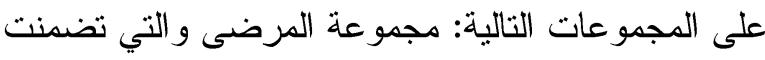

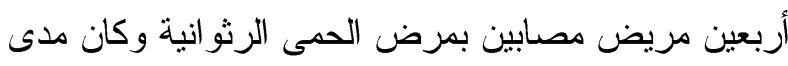
أعمار المرضى مابين ( 20-70) سنة وعدد الذكور ( ) (17.5 \% و الإناث ( 33) (82.5\%). مجموعة الأصحاء: جمعت ثلاثة عشر عينة مصل من أفر اد أصحاء ظاهريا وكان مدى أعمار لأصحاء مابين ( 23-59) سنة. أظهرت مينه

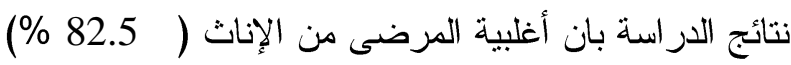

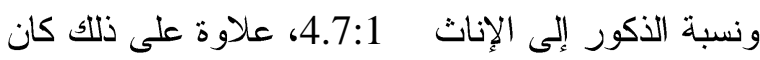
متوسط العمر لمجموعتين المرضى و السيطرة ( 46.38 ـ

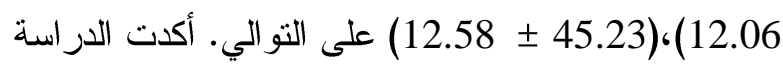
بان نسبة انتشار مرض الحمى الرثو انية في الإناث (82.5\%) وفي الذكور ( 17.5\%) وبينما معدل موجبيه

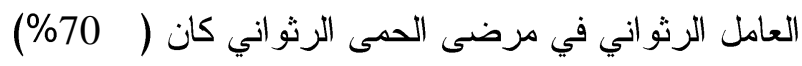

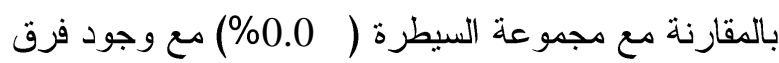
معنوي ، من ناحية أخرى أوضحت الدراسة بان نسبة

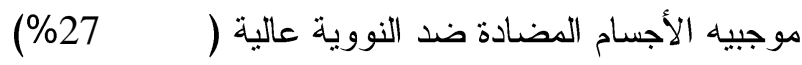

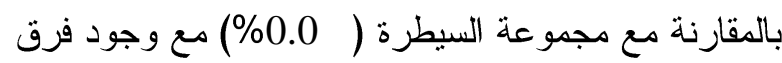
معنوي ، فضلا على ذلك أكدت الدراسة بان نسبة الايجابية

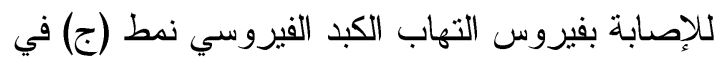
مرضى الحمى الرثوانية كانت (5\%) بالمقارنة مع مجموعة

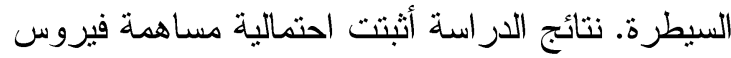
التهاب الكبد نمط (ج) في أمر اضية الحمى الرثو انية. 